\title{
Perancangan Kios Buku Online Dengan Menerapkan Algoritma MD5 Dalam Pengamanan Record Login
}

\author{
${ }^{1)}$ Amin Setiawan Lahagu \\ STMIK Budi Darma, JI. Sisimangaraja No.338 Medan, Sumatera Utara, Indonesia \\ www.stmik-budidarma.ac.id // Email : lahagua1@gmail.com \\ 2) Harvei Desmon Hutahaean \\ STMIK Pelita Nusantara, JI. Iskandar Muda No. 1 Medan, Sumatera Utara, Indonesia \\ www.stmik-budidarma.ac.id // Email : harvei.budidarma@gmail.com
}

\begin{abstract}
Online book stall is one form of e-commerce in cyberspace, all the time the sale and purchase transactions of books can be done at any time, but along with the development of online transactions, data controls should also be improved. To avoid data from damage caused by irresponsible people, it is necessary to secure data by applying cryptography to the data.

In modern times there are many methods or algorithms that can be used to protect and control data from various attacks, but each of these algorithms certainly has its own weaknesses and strengths. The need for long-distance transactions and the importance of data security caused developers to continue to develop cryptography. MD5 algorithm is a one-way hash function that is often used in cryptography, especially in web-based transactions. The MD5 algorithm encodes data in a constant form of 32 bits. All processes from sales and purchase transactions in online bookstores will be safe and durable when the bookstore database is designed in such a way. The book stall database records are encoded with the MD5 algorithm, especially for logging records as a gateway for hackers or hackers to infiltrate. All transactions in the online book kiosk system are detected by the database, the resilience of the database from all attacks is the control of the system from all kinds of damage.
\end{abstract}

Keywords: Online book stall, Cryptography, MD5 hash algorithm.

\section{PENDAHULUAN}

Kios buku online adalah salah satu bentuk $e$ commerce yang memungkinkan terjadinya pasar di dunia maya, berkembangnya teknologi informasi membuka lapangan kerja baru kepada banyak orang. Kios buku online merupakan transformasi dari toko buku konvensional yang terbatas dalam memberikan informasi terhadap persediaan buku yang dimiliki. Kios buku online menyediakan buku dalam bentuk soft copy ataupun hard copy, penyediaan dalam bentuk soft copy, selain menawarkan produk yang portable juga efisien cenderung murah. Mudahnya melakukan transaksi online khususnya kios buku online menambah persaingan yang semakin hari semakin sengit, juga kios buku online sangat efektif dan selalu mengupdate informasi buku secara aktual.

Seiring berkembangnya transaksi melalui internet khususnya penjualan dan pembelian buku secara online, kejahatan semakin meningkat mulai dari pencurian password, melakukan pengubahan data rahasia bahkan melakukan penipuan dan pemalsuan diri untuk pembobolan kartu belanja. Cracker di dunia maya berusaha masuk ke database untuk melakukan pengrusakan. Pengamanan sekarang tidak hanya dibebankan pada firewall ataupun pada instrusion system detection tetapi pada database dengan cara melakukan penyandian terhadap record database tersebut sehingga sekalipun seorang cracker masuk ke database tetapi tidak bisa membaca isi asli dari database tersebut karena dalam bentuk ciphertext. Cracker melakukan aksinya dengan mencari trap-door dalam website, dalam hal ini memanfaatkan form login sebagai pintu masuknya.

Pengamanan database bisa dilakukan dengan menyandikan record database tersebut dengan algoritma hash message 
digest 5. Fungsi algoritma md5 terhadap keamanan login mencakup aspek nonrepudataion, data integrity, user authetication, dan privacy. Algoritma message digest 5 merupakan perbaikan dari algoritma message digest 4 yang sama-sama menghasilkan message digest sepanjang 128 bit. Algoritma md5 mengolah pesan dalam blok 512 bit setelah melewati tahap penambahan padding bit, tahap penambahan nilai panjang pesan semula dan tahap inisialisasi buffer message digest. Algoritma message digest 5 merupakan algoritma hash satu arah, dimana ciphertext tidak bisa dikembalikan ke bentuk asli baik dengan menggunakan algoritma ataupun kunci. Chiphertext tidak bisa dimodifikasi, ciphertext tidak bisa digunakan untuk login ke dalam sistem sehingga membatasi ruang gerak cracker untuk menyerang ${ }^{[3]}$.

Berdasarkan uraian latar belakang di atas, maka rumusan masalah pada penelitian ini adalah sebagai berikut : Bagaimana proses enkripsi menggunakan algoritma hash md5?, Bagaimana merancang antarmuka kios buku online?, Bagaimana cara menerapkan algoritma hash md5 dalam pengamanan kios buku online?

Adapun tujuan penelitian ini adalah sebagai berikut :

1. Mengenkripsi record login database kios buku menggunakan algoritma $m d 5$.

2. Merancang antarmuka kios buku online.

3. Menerapkan algoritma md5 untuk pengamanan kios buku online.

Adapun manfaat penelitian ini adalah sebagai berikut :

1. Mengamankan kios buku online dari berbagai serangan cracker atau hacker.

2. Meningkatkan kenyamanan pengguna dalam menggunakan kios buku online.

\section{LANDASAN TEORI}

\subsection{Kriptografi}

Kriptografi berasal dari bahasa Yunani, menurut bahasa dibagi menjadi dua kripto dan graphia, kripto berarti secret (rahasia) dan graphia berarti writing (tulisan). Menurut teminologinya kriptografi adalah ilmu dan seni untuk menjaga keamanan pesan ketika pesan dikirim dari satu tempat ke tempat lain ${ }^{[3]}$.

\subsubsection{Fungsi hash}

Fungsi hash adalah fungsi yang menerima masukan string yang panjangnya sembarang dan mengkonversinya menjadi string keluaran yang panjangnya tetap (fixed), umumnya berukuran jauh lebih kecil daripada ukuran string semula. Fungsi hash dapat menerima masukan string apa saja. Jika string menyatakan pesan (message), maka sembarang pesan $M$ berukuran bebas dikompresi oleh fungsi hash $H$ melalui persamaan

$h=H(M)$

Keluaran fungsi hash disebut juga nilai hash (hash-value) atau pesan ringkas (message digest). Pada persamaan (2.1), $h$ adalah nilai hash atau message digest dari fungsi $H$ untuk masukan $M$. Dengan kata lain, fungsi hash mengkompresi sembarang pesan yang berukuran berapa saja menjadi message digest yang ukurannya selalu tetap (dan lebih pendek dari panjang pesan semula). Gambar 1 memperlihatkan contoh 3 buah pesan dengan panjang yang berbeda-beda selalu dihash menghasilkan pesan ringkas yang panjangnya tetap (dalam contoh ini pesan ringkas dinyatakan dalam kode hexadesimal yang panjangnya 128 bit .

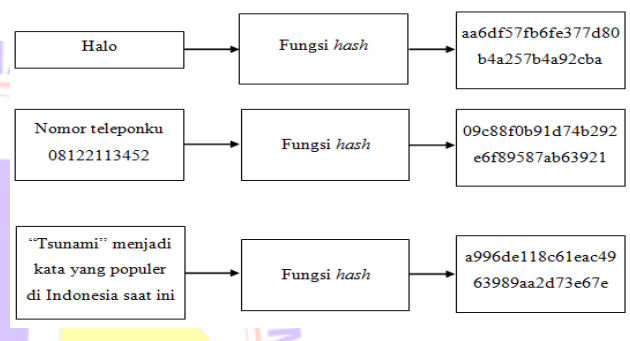

Gambar 1 Contoh hashing beberapa buah pesan $^{[2]}$

\subsubsection{MD5}

MD5 adalah salah satu penggunaan fungsi hash satu arah yang paling banyak digunakan. MD5 merupakan fungsi hash kelima yang dirancang oleh Ron Rivest dan didefinisikan pada RFC 1321. MD5 merupakan pengembangan dari MD4 dimana terjadi penambahan satu ronde. MD5 memproses teks masukan ke dalam block-block bit sebanyak 512 bit, dibagi ke dalam 32 bit subblock sebanyak 16 buah. Keluaran dari MD5 berupa 4 buah block yang masing-masing 32 bit yang mana akan menjadi 128 bit yang biasa disebut nilai hash

\subsubsection{Cara Kerja MD5}

MD5 mengolah block 512 bit, dibagi ke dalam 16 subblock berukuran 32 bit. Keluaran algoritma diset menjadi 4 block yang masingmasing berukuran 32 bit yang setelah digabungkan akan membentuk nilai hash 128 bit. Adapun langkah-langkah pembuatan message digest adalah sebagai berikut:

\subsection{Penambahan Bit-bit Pengganjal}


Pesan ditambah dengan sejumlah bit pengganjal sedemikian sehingga panjang pesan (dalam satuan bit) kongruen dengan 448 modulo 512. Ini berarti panjang pesan setelah ditambahi bit-bit pengganjal adalah 64 bit kurang dari kelipatan 512. Angka 512 ini muncul karena md5 memproses pesan dalam blok-blok yang berukuran 512. Pesan dengan panjang 448 bit pun tetap ditambah dengan bit-bit pengganjal. Jika panjang pesan 448 bit, maka pesan tersebut ditambah dengan 512 bit menjadi 960 bit. Jadi, panjang bit-bit pengganjal adalah antara 1 sampai 512 . Bit-bit pengganjal terdiri dari sebuah bit 1 diikuti dengan sisanya bit $0^{[2]}$

\subsection{Penambahan Nilai Panjang Semula}

Pesan yang telah diberi bit-bit pengganjal selanjutnya ditambah lagi dengan 64 bit yang menyatakan panjang pesan semula. Jika panjang pesan $>2^{64}$ maka yang diambil adalah panjangnya dalam modulo $2^{64}$. Dengan kata lain, jika panjang pesan semula adalah $\mathrm{K}$ bit, maka 64 bit yang ditambahkan menyatakan $\mathrm{K}$ modulo $2^{64}$. Setelah ditambah dengan 64 bit, panjang pesan sekarang menjadi kelipatan 512 bit $^{22 .}$

\subsection{Inisialisasi Penyangga $M D$}

MD5 membutuhkan 4 buah penyangga (buffer) yang masing-masing panjangnya 32 bit. Total panjang penyangga adalah $4 \times 32=128$ bit. Keempat penyangga ini menampung hasil antara dan hasil akhir. Keempat penyangga ini diberi nama $A, B, C$, dan $D$. Setiap penyangga diinisialisasi dengan nilai-nilai (dalam notasi HEX) sebagai berikut: $A=012345678, B=$ 89ABCDEF, $C=$ FEDCBA98, $D=76543210$ dan beberapa versi MD5 menggunakan nilai inisialisasi berbeda, yaitu: $A=67452301, B=$ EFCDAB89, $C=98$ BADCFE, $D=10325467$. (Rinaldi Munir, 2006, hal. 221).

\subsection{Pengolahan Blok Berukuran 512 bit}

Pesan dibagi menjadi $L$ buah blok yang masing-masing panjangnya 512 bit ( $Y_{0}$ sampai $\left.Y_{\mathrm{L}-1}\right)$. Setiap blok 512 bit diproses bersama dengan penyangga $M D$ menjadi keluaran 128 bit, dan ini disebut proses $H_{M D 5}$. Pada $m d 5$ juga terdapat 4 (empat) buah fungsi nonliniear yang masing-masing digunakan pada tiap operasinya (satu fungsi untuk satu block). Adapun fungsi tersebut sebagai berikut:

$$
\begin{aligned}
& \mathrm{F}(X, Y, Z)=\left(X^{\wedge} \mathrm{Y}\right) \mathbf{v}((\neg X) \wedge Z)(2) \\
& \mathrm{G}(X, Y, Z)=\left(X^{\wedge} Z\right) \mathbf{v}(Y \wedge \neg Z)(3) \\
& H(X, Y, Z)=X \oplus \quad Y \oplus Z(4) \\
& \mathrm{I}(X, Y, Z)=Y \oplus\left(X^{\vee}(\neg Z)\right)(5)
\end{aligned}
$$

Adapun yang dilakukan setelah tahap pengolahan blok 512 bit adalah melakukan operasi-operasi sebagai berikut :

$\mathrm{FF}\left(\mathrm{a}, \mathrm{b}, \mathrm{c}, \mathrm{d}, \mathrm{M}_{\mathrm{j}}, \mathrm{s}, \mathrm{ti}\right)(6)$

$\mathrm{GG}\left(\mathrm{a}, \mathrm{b}, \mathrm{c}, \mathrm{d}, \mathrm{M}_{\mathrm{i}}, \mathrm{s}, \mathrm{ti}\right)(7)$

$\mathrm{HH}\left(\mathrm{a}, \mathrm{b}, \mathrm{c}, \mathrm{d}, \mathrm{M}_{\mathrm{j}}, \mathrm{s}, \mathrm{ti}\right)(8)$

II $\left(\mathrm{a}, \mathrm{b}, \mathrm{c}, \mathrm{d}, \mathrm{M}_{\mathrm{j}}, \mathrm{s}, \mathrm{ti}\right)(9)$

$\mathrm{FF}\left(\mathrm{a}, \mathrm{b}, \mathrm{c}, \mathrm{d}, \mathrm{M}_{\mathrm{j}}, \mathrm{s}, \mathrm{t}, \mathrm{i}\right)$ menunjukkan $\mathrm{a}=\mathrm{b}+((\mathrm{a}+$ $\left.\left.F(b, c, d)+M_{j}+t i\right) \ll<s\right), G G\left(a, b, c, d, M_{j}, s, t i\right)$ menunjukkan $\mathrm{a}=\mathrm{b}+\left(\left(\mathrm{a}+\mathrm{G}(\mathrm{b}, \mathrm{c}, \mathrm{d})+\mathrm{M}_{\mathrm{j}}+\mathrm{ti}\right)\right.$ $\ll<s), H H\left(a, b, c, d, M_{j}, s, t i\right)$ menunjukkan $a=b$ $+\left(\left(a+H(b, c, d)+M_{j}+\mathrm{ti}\right) \ll s\right)$, II $\left(\mathrm{a}, \mathrm{b}, \mathrm{c}, \mathrm{d}, \mathrm{M}_{\mathrm{j}}, \mathrm{s}, \mathrm{ti}\right)$ menunjukkan $\mathrm{a}=\mathrm{b}+((\mathrm{a}+$ $\left.\left.\mathrm{I}(\mathrm{b}, \mathrm{c}, \mathrm{d})+\mathrm{M}_{\mathrm{j}}+\mathrm{ti}\right) \ll<\mathrm{s}\right) . \mathrm{M}_{\mathrm{j}}$ menggambarkan pesan ke-j dari subblock (dari 0 sampai 15) dan $\ll<s$ s menggambarkan bit akan digeser ke kiri sebanyak s bit.

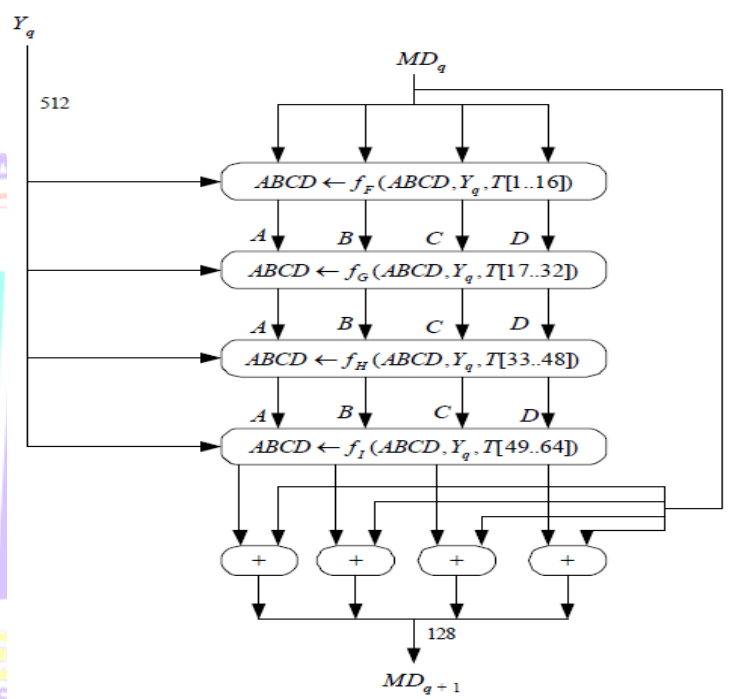

Gambar 2 Pengolahan blok 512 bit (Proses MD5) ${ }^{[2]}$

Proses $H_{m d 5}$ terdiri dari 4 buah putaran, dan masing-masing putaran melakukan operasi dasar $m d 5$ sebanyak 16 kali dan setiap operasi dasar memakai sebuah elemen $T$. Jadi setiap putaran memakai 16 elemen Tabel $T$. $Y_{q}$ menyatakan blok 512 bit ke-q dari pesan yang telah ditambah bit-bit pengganjal dan tambahan 64 bit nilai panjang pesan semula. $M D_{q}$ adalah nilai message digest 128 bit dari proses $H_{m d 5}$ ke- $q$. Pada awal proses, $M D_{q}$ berisi nilai inisialisasi penyangga $M D$.

Keluaran dari $m d 5$ adalah 128 bit dari word terendah $\mathrm{A}^{[2] \text {. }}$

\section{PEMBAHASAN}

\subsection{Analisa Masalah}

Pada bagian pembahasan masalah disini, akan dianalisa bagaimana cara kerja algoritma hash md5 dalam mengenkripsi record pada database kios buku. Database kios buku ini dinamakan kios_data. Kios buku terdiri dari 
beberapa tabel yaitu tabel kios_admin, tabel kios_buku, tabel kios_belanja, tabel kios_member, tabel kios_guestbok, tabel news. Maka, proses mengenkripsi record pada database tersebut dengan menggunakan algoritma $m d 5$, akan dibagi dalam beberapa tahap yang dijelaskan pada subbab-subbab berikut ini.

\subsubsection{Analisis Penambahan Bit-bit Pengganjal}

Adapun record pada database yang dimaksud di atas menunjuk pada tabel kios_admin seperti pada tabel berikut ini:

Database : kios_data

\section{Tabel 1 Record pada tabel kios_admin}

\begin{tabular}{|l|l|l|l|l|}
\hline Id & User & Pass & Sesj & Aktif \\
\hline 1 & AMINSLAHAGU & ADM11 & Hash (User $+P_{\text {ass })}$ & 1 \\
\hline
\end{tabular}

Pada tabel 1 di atas diambil contoh untuk record AMINSLAHAGU pada field user. Kemudian record tersebut diubah ke dalam bentuk hexadecimal sebagai berikut ini:
a. Plaintext $=$ AMINSLAHAGU
b. Dalam hexa $=414 \mathrm{D} 494 \mathrm{E} 534 \mathrm{C} 4148414755$
c. Panjang Plaintext $=88$ bit
d. Panjang bit pengganjal $=(448$ module 512$)$
-88 bit $=360$
e. $B i-b i t$ pengganjal dalam biner $=$
$\begin{array}{lllll}01010011 & 01001100 & 01000001 & 01001000\end{array}$
$\begin{array}{lllll}01000001 & 01000111 & 01010101 & 10000000\end{array}$
$00000000 \quad 00000000 \quad 00000000 \quad 00000000$
$00000000 \quad 00000000 \quad 00000000 \quad 00000000$
$00000000 \quad 00000000 \quad 00000000 \quad 00000000$
$00000000 \quad 00000000 \quad 00000000 \quad 00000000$
$00000000 \quad 00000000 \quad 00000000 \quad 00000000$
$00000000 \quad 00000000 \quad 00000000 \quad 00000000$
$00000000 \quad 00000000 \quad 00000000 \quad 00000000$
$00000000 \quad 00000000 \quad 00000000 \quad 00000000$
$00000000 \quad 00000000 \quad 00000000 \quad 00000000$
$00000000 \quad 00000000 \quad 00000000 \quad 00000000$
00000000000000000000000000000000
f. Maka, Plaintext $(P)=$
$\begin{array}{llllllllllll}41 & 4 \mathrm{D} & 49 & 4 \mathrm{E} & 53 & 4 \mathrm{C} & 41 & 48 & 41 & 47 & 55 & 80\end{array}$
$\begin{array}{llllllllllll}00 & 00 & 00 & 00 & 00 & 00 & 00 & 00 & 00 & 00 & 00 & 00\end{array}$
$\begin{array}{llllllllllll}00 & 00 & 00 & 00 & 00 & 00 & 00 & 00 & 00 & 00 & 00 & 00\end{array}$
$\begin{array}{llllll}00 & 00 & 00 & 00 & 00 & 00\end{array}$
$\begin{array}{llllllllllll}00 & 00 & 00 & 00 & 00 & 00 & 00 & 00 & 00 & 00 & 00 & 00\end{array}$ 0000

\subsubsection{Analisis Penambahan Panjang Plaintext}

Setelah penambahan bit-bit pengganjal pada plaintext kemudian dilanjutkan dengan penambahan panjang pesan semula dan diikuti dengan penambahan 64 bit bilangan 0 sehingga plaintext berjumlah genap 512 bit . Adapun langkah-langkah penambahan tersebut sebagai berikut ini. a. $P_{\text {awal }}($ Hexa $)=$

41 4D 49 4E 53 4C 4148414755

b. $\mathrm{P}_{\text {awal }}($ Biner $)=$

01000001010011010100100101001110

01010011010011000100000101001000

0100000101000111

01010101

c. Panjang pesan semula $=88$ bit

d. Maka, $P=$

41 4D 49 4E 53 4C 4148414755800000 000000000000000000000000000000 000000000000000000000000000000 000000000000000000000058000000 0000000000

\subsubsection{Inisialisasi Penyangga Message Digest}

Tahap inisialisasi karena beberapa versi MD5 memiliki nilai inisialisasi berbeda maka penulis memilih salah satu dari beberapa inisialisasi yang ditentukan, $\mathrm{A}=67452301, \mathrm{~B}=$ EFCDAB89, $C=$ 98BADCFE, $D=10325476$.

\subsubsection{Pembagian Plaintext dalam $L$ buah block $\left(\mathrm{Y}_{0}-\mathrm{Y}_{\mathrm{L}-1}\right)$}

Pada tahap ini padding bit dimasukkan ke dalam array:

$\mathrm{X}[0]=4 \mathrm{e} 494 \mathrm{~d} 41$

$X[1]=48414 \mathrm{c} 53$

$X[2]=80554741$

$X[3]=00000000$

$X[4]=00000000$

$X[5]=00000000$

$X[6]=00000000$

$\mathrm{X}[7]=00000000$

$\mathrm{X}[8]=00000000$

$X[9]=00000000$

$X[10]=00000000$

$X[11]=00000000$

$X[12]=00000000$

$X[13]=00000000$

$X[14]=00000058$

$X[15]=00000000$

\subsubsection{Proses Operasi MD5}

Adapun persamaan untuk proses MD5 tersebut adalah $=$

Round 1: $\mathrm{a}=\mathrm{b}+((\mathrm{a}+\mathrm{F}(\mathrm{b}, \mathrm{c}, \mathrm{d})+\mathrm{X}[\mathrm{k}]+\mathrm{T}[\mathrm{i}])$ $<<$ S)

Fungsi yang digunakan pada masukan $\mathrm{F}(\mathrm{b}, \mathrm{c}, \mathrm{d})=(\mathrm{b} \wedge \mathrm{c}) \vee((\sim \mathrm{b}) \wedge \mathrm{d})$

Operasi 1:

FF (a, b, c, d, x[0], 0xD76AA478)

FF : $a=67452301, b=$ efcdab89, $c=$ 98badcfe, $d=10325476, x 0=4 e 494 d 41$,

$\mathrm{s}=7, \mathrm{ti}=\mathrm{d} 76 \mathrm{aa} 478$

$\mathrm{F}=($ efcdab89 $\wedge$ 98badcfe $) \vee((\sim$ efcdab89 $) \wedge$ 10325476)

$=(88888888) \vee(10325476)$

$=98 \mathrm{badcfe}$ 


$$
\begin{aligned}
& \mathrm{a}+\mathrm{F}(\mathrm{b}, \mathrm{c}, \mathrm{d})+\mathrm{x} 0+\mathrm{ti}=67452301+ \\
& \text { 98badcfe }+4 \mathrm{e} 494 \mathrm{~d} 41+\mathrm{d} 76 \mathrm{aa} 478 \\
& =225 \mathrm{~b} 3 \mathrm{f} 1 \mathrm{~b} 8 \bmod 2^{32} \\
& =25 \mathrm{~b} 3 \mathrm{f} 1 \mathrm{~b} 8=00100101101100111111 \\
& 000110111000 \\
& C L S_{\mathrm{s}}(\mathrm{a}+\mathrm{F}(\mathrm{b}, \mathrm{c}, \mathrm{d})+\mathrm{x} 0+\mathrm{ti})= \\
& \mathrm{CLS}_{7}(25 \mathrm{~b} 3 \mathrm{f} 1 \mathrm{~b} 8) \\
& \text { = } 11011001111110001101110000010010 \\
& =\mathrm{d} 9 \mathrm{f} 8 \mathrm{dc} 12 \\
& =b+d 9 f 8 d c 12 \\
& =(\text { efcdab89 }+\mathrm{d} 9 \mathrm{f} 8 \mathrm{dc} 12) \bmod 2^{32} \\
& =\mathrm{c} 9 \mathrm{c} 6879 \mathrm{~b}
\end{aligned}
$$

\section{ALGORITMA DAN IMPLEMENTASI}

\subsection{Algoritma}

Algoritma merupakan langkah-langkah yang tersusun secara sistematis untuk menyelesaikan suatu masalah atau menerangkan sesuatu hal yang akan dilakukan. Algoritma digunakan untuk menganalisa serta menjelaskan urutan dan hubungan antara kegiatan yang akan ditempuh. Dalam skripsi ini penulis membuat algoritma sebagai berikut.

\subsubsection{Algoritma Pengamanan Record}

Adapun algoritma pengamanan record menggunakan algoritma md5 di bawah ini, dalam mengenkripsi suatu plaintext bahwa semua penyangga adalah 32 bit dan penjumlahan dalam modula $2^{\wedge} 32$.

$$
\begin{aligned}
\text { Input } & =\mathrm{P}_{\mathrm{i}} \leftarrow \text { Plaintext } \\
& =\mathrm{A} \leftarrow \text { Penyangga } \\
& =\mathrm{B} \leftarrow \text { Penyangga } \\
& =\mathrm{C} \leftarrow \text { Penyangga }
\end{aligned}
$$$$
\text { id }
$$$$
\text { user }
$$

.

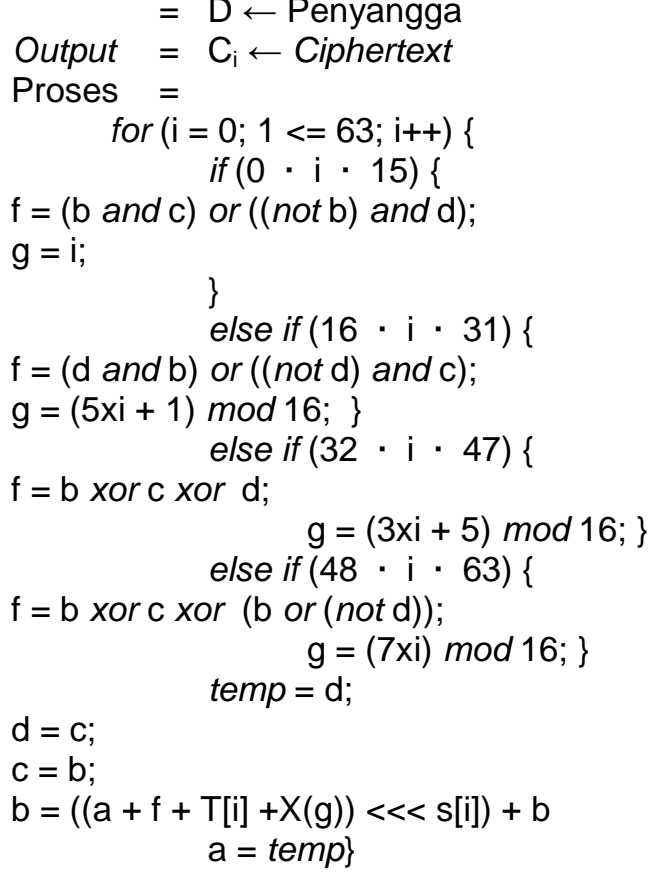

\begin{tabular}{|c|c|c|c|c|}
\hline$\leftarrow \top \rightarrow$ mid & user & pass & sesi & nama \\
\hline$\square \times 3$ & 3 c9d2cce909ea37234be8af1a1f958805 & 707 bedd 98 d8abd4346de 94 fffa 35 b5c5 & 5850 ce 4501 dddf $8 f 0 f c 5 f c c 1 b 2 e 293 d 8$ & $\begin{array}{l}\text { Annisa } \\
\text { Wulandari }\end{array}$ \\
\hline$\square \times 7$ & 7 ee11cbb19052e40b07aac0ca060c23ee & $5 f 4 d c c 3 b 5 a a 765 d 61 d 8327$ deb882cf99 & 3ae9ea5fe7ad5bf652c51f43da57422c & sdasfas \\
\hline$\square \times 17$ & 7 Ofe 6 de $04749 d 3 c 8 d f 173111775548 a 0 a$ & $73 a c d 9 a 5972130$ b75066c82595a1fae3 & e21ed2761975351469bfc2550b79df00 & $\begin{array}{l}\text { AMIN } \\
\text { SETIAWAN } \\
\text { LAHAGU }\end{array}$ \\
\hline
\end{tabular}

\subsection{Implementasi}

Pengujian sistem merupakan proses mencoba aplikasi apakah telah sesuai dengan rancangan sebelumnya, sehingga bisa dipastikan apakah hasil dari pada eksekusi program telah sesuai dengan output dari tujuan perancangan, melakukan pengecekan dari proses enkripsi yang dilakukan apakah sesuai dengan perhitungan algoritma $m d 5$.

\subsubsection{Tampilan Record Login User}

Adapun pada gambar di bawah terlihat ada field user, pass, dan sesi masing-masing memiliki panjang yang tetap karena disandikan dengan algoritma MD5.

\section{Gambar 3. Tampilan Record Login User}

\section{KESIMPULAN DAN SARAN}

\subsection{Kesimpulan}

Setelah menyelesaikan penelitian ini, penulis berkesimpulan sebagai berikut:

1. Panjang atau pendek dari plaintext yang akan disandikan tidak berpengaruh terhadap kecepatan karena setiap plaintext harus dalam bentuk block-block 512 bit. Penyandian menggunakan algoritma md5 membutuhkan 64 operasi dan setiap operasi mengalami pergeseran secara sikuler. Penyandian secara manual harus memiliki ketelitian yang tinggi karena kesilafan 1 bit saja menyebabkan kesalahan fatal kecuali diulangi dari awal. Struktur algoritma yang digunakan tidak terlalu rumit, cukup dengan pemahaman operasi sitem bilangan.

2. Alat bantu untuk merancang kios buku bisa dilakukan dengan menggunakan UML dan DFD. Untuk perancangan juga diperlukan konsistensi terhadap tampilan, 
struktur dari database disesuaikan dengan ukuran data yang akan disimpan, dalam hal ini md5 memerlukan ukuran record yang tetap.

3. Dengan memanfaatkan fungsi yang didukung oleh pemrograman php maka proses penyandian dalam pengamanan record login sangat mudah dilakukan. Record yang sudah dienkripsi memiliki panjang karakter yang tetap yaitu 32 karakter.

\subsection{Saran}

Untuk menyempurnakan penelitian ini dan benar-benar bermanfaat maka ada beberapa saran penulis adalah sebagai berikut:

1. Algoritma $m d 5$ adalah salah satu fungsi hash satu arah dari berbagai algoritma hash yang lain, algoritma md5 menghasilkan ciphertext sepanjang 128 bit. Untuk pengembangan selanjutnya diperlukan algoritma yang lebih kuat seperti SHA yang menghasilkan ciphertext lebih panjang yaitu 160 bit, SHA memerlukan 5 penyangga dibanding $m d 5$ yang memerlukan 4 penyangga saja.

2. Pengamanan sistem bisa dikembangkan dengan menerapkan pada record gambar misalnya untuk pengamanan kartu belanja.

3. Untuk pengamanan web yang lebih aman maka diperlukan penyandian terhadap seluruh record dari database, tidak hanya pada record login saja.

\section{DAFTAR PUSTAKA}

1. Dony Ariyus, "Keamanan Data dan Komunikasi", Penerbit Graha IImu, Yogyakarta, Edisi 1, 2006

2. Rinaldi Munir, "Kriptografi", Penerbit Informatika Bandung, Bandung, 2006

3. Dony Ariyus, Rum Andri K.R, "Komunikasi Data", Penerbit Andi, Yogyakarta, Edisi 1, 2008

4. Kusrini, "Konsep dan Aplikasi Sistem Pendukung Keputusan", Penerbit Andi, Yogyakarta, Edisi 1, 2007

5. Aghus Sofwan etc., "Aplikasi Kriptografi dengan Algoritma Message Digest 5 (MD5)", 2006, Jurnal Teknik Elektro Fakultas Universitas Diponegoro

6. Jogiyanto H.M, "Analisa dan Sistem Informasi”, Penerbit Andi, Yogyakarta, 1999

7. Ibnu Aqil, "Sistem Informasi Alumni Program Diploma Pada Bina Sriwijaya Palembang Berbasis Web", 2010, Jurnal Akademi Manajemen Informatika dan Komputer Bina Sriwijaya Palembang
8. http://www.duniailkom.com/pengertiandan-fungsi-php-dalam-pemograman-web/, tanggal akses 26 Maret 2015

9. http://www.kamusilmiah.com/it/mengenalapa-itu-html-hyper-text-markup-language/

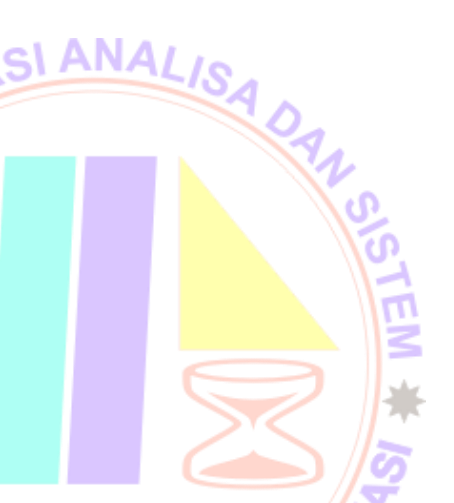

